\title{
HUBUNGAN PENGETAHUAN DENGAN PERILAKU DETEKSI DINI PENYAKIT TB PARU
}

\author{
Wahid Tri Wahyudi', Suprihatin ${ }^{2}$
}

1Program Studi IImu Keperawatan Universitas Malahayati Bandar Lampung. Email : wahid@malahayati.ac.id 2Puskesmas Negeri Agung Kabupaten Way Kanan. Email : supri_wk@yahoo.com

\section{ABSTRACT: KNOWLEDGE AND DETECTION OF PULMONARY TUBERCULOSIS AMONG COMMUNITY IN LAMPUNG-INDONESIA}

Background: Tuberculosis of Lung is an infectious disease caused by the bacterium mycobacterium tuberculosis, which most commonly affects the lungs. Mortality and morbidity due to mycobacterium tuberculosis bacteria in indonesia in 2009 there were 1.7 million people died. The incidence of tuberculosis of lung in Lampung until the end of December 2015, tuberculosis of lung is 8,492 cases from the estimated cases in 2015 as many as 32,128 . Efforts to prevent the increase in cases of tuberculosis in Indonesia carried out with a description of the case detection efforts can be measured by knowing the number of TB cases found and recorded indicators of Case Notification Rate (CNR).

Purpose: This study aims to determine the relationship of knowledge with the early detection tuberculosis of lung in the work area of the Way Kanan public health center district in 2017.

Methods: The type of this research is quantitative research with cross sectional approach. The population in this research is all citizens suspect in working area of Public Health Center of Way Kanan regency. Instrument of data collection in this research use questioner. The data analysis used is chi square.

Results: The statistical results show that there is a correlation between knowledge with early detection of pulmonary tuberculosis ( $p$ value $=0,00$ ).

Counclusion: Suggestions in the research are expected to motivate the community to actively participate in lung tuberculosis examination program.

Keywords : Pulmonary, tuberculosis, knowledge, detection.

Pendahuluan: Tuberkulosis Paru (TB Paru) adalah penyakit menular yang disebabkan oleh bakteri mycobacterium tuberculosis, yang paling umum mempengaruhi paru-paru. Angka kematian dan kesakitan akibat kuman mycobacterium tuberculosis di indonesia pada tahun 2009 terdapat 1,7 juta orang meninggal. Angka kejadian TB paru di Lampung hingga akhir Desember tahun 2015, angka penemuan kasus penderita TB paru sebanyak 8.492 kasus dari estimasi kasus di tahun 2015 sebanyak 32.128. Upaya pencegahan peningkatan kasus TBC di Indonesia dilakukan dengan gambaran upaya penemuan kasus dapat diukur dengan mengetahui banyaknya kasus TB yang ditemukan dan tercatat indikator Case Notification Rate (CNR).

Tujuan : Penelitian ini bertujuan untuk mengetahui hubungan pengetahuan dengan upaya deteksi dini penyakit tb paru di wilayah kerja puskesmas Negeri Agung kabupaten Way Kanan tahun 2017.

Metode : Jenis penelitian ini adalah penelitian kuantitatif dengan pendekatan cross sectional. Populasi dalam penelitian ini adalah semua warga suspect di wilayah kerja puskesmas Negeri Agung kabupaten Way Kanan. Sampel dalam penelitian ini sebanyak 133 pasien. Tehnik pengambilansampel dengan metode Cross sectional.Analisa data menggunakan uji chi square.

Hasil penelitian : Hasil penelitian menunjukkan terdapat hubungan antara pengetahuan dengan upaya deteksi dini penyakit tuberkulosis paru ( $p$ value $=0,00$ ).

Simpulan: Peneliti menganjurkan agar Puskesmas melakukan pencegahan berupa; Melakukan pencegahan deteksi dini melalui pemeriksaan-pemeriksaan sesuai kebijakan yang telah ditetapkan puskesmas dan Memotivasi masyarakat supaya aktif berpartisipasi dalam program pemeriksaan tuberkulosis paru

Kata kunci:Tuberkulosis Paru (TBC),Pengetahuan, Upaya Deteksi Dini 
HUBUNGAN PENGETAHUAN DENGAN PERILAKU DETEKSI DINI PENYAKIT TB PARU

\section{PENDAHULUAN}

TBC adalah penyakit menular yang disebabkan oleh bakteri Mycobacterium tuberculosis, yang paling umum mempengaruhi paru-paru. Penyakit ini ditularkan dari orang ke orang melalui cairan dari tenggorokan dan paruparu seseorang dengan penyakit pernapasan aktif (World Health Organitation, 2012; Denila, \& Samingan, 2017).

Tuberkulosis (TBC) masih menjadi masalah kesehatan global. Sepertiga dari populasi dunia sudah tertular dengan TBC dimana sebagian besar penderita TBC adalah usia produktif (15-55 tahun). Hal ini menyebabkan kesehatan yang buruk di antara jutaan orang setiap tahun dan menjadi penyebab utama kedua kematian dari penyakit menular diseluruh dunia, setelah Human Immunodeficiency Virus (HIV)/AIDS (Acquired Immune Deficiency Syndrome). Pada tahun 2012 terdapat 9 juta kasus baru dan 1,4 juta kematian akibat penyakit TBC dan HIV (World Health Organitation, 2012).

Indonesia dimata dunia sudah menduduki peringkat kedua dibawah India diatas Cina karena sejak 2015 hasil surveilens menyatakan prevalens TB mencapai 647 per 100.000 dan insiden 399, serta diprediksi akan mencapai 1 juta kasus pertahun. Kasus TB MDR di Indonesia diestimasi sekitar 6600 per tahun, kisaran $88 \%$ dari kelompok pengobatan ulang sudah dilakukan diagnosis sehingga tercatat lebih dari 1800 kasus terdiagnosis dengan 1200 mendapatkan pengobatan (Kementrian Kesehatan Republik Indonesia, 2012; Syarah \& Rahmawati, 2017).

Angka kematian dan kesakitan akibat kuman Mycobacterium tuberculosis di Indonesia sangatlah tinggi. Tahun 2010 Indonesia telah berhasil menurunkan insidens, prevalensi, dan angka kematian (Departemen kesehatan Republik Indonesia, 2011; Astuti, 2013).

Indonesia berpeluang mencapai penurunan angka kesakitandan kematian akibat TB menjadi setengahnya di tahun 2015 jika dibandingkan dengan data tahun 1990. Angka prevelensi TB yang pada 1990 sebesar 443 per 100.000 penduduk, pada tahun 2015 ditargetkan menjadi 280 per 100.000 pendduduk . berdasarkan hasil survei prevelensi TB tahun 2013 prevelensi TB paru smear positif per 100.000 penduduk umur 15 tahun keatas sebesar 257 TBC masih merupakan masalah kesehatan penting di dunia dan di Indonesia. TBC juga merupakan salah satu indikator keberhasilan MDGs yang harus dicapai oleh Indonesia, yaitu menurunkan angka kesakitan dan angka kematian menjadi setengahnya di tahun 2015 (Kementrian Kesehatan Republik Indonesia, 2016).

Upaya pencegahan peningkatan kasus TBC di indonesia dilakukan dengan gambaran upaya penemuan kasus dapat diukur dengan mengetahui banyaknya kasus TB yang ditemukan dan tercatat indikator Case Notification Rate (CNR). CNR merupakan jumlah kasus TB baru yang ditemukan dan dicatat diantara 100.000 penduduk diwilayah dan periode waktu tertentu (Anggreny, 2018).

Untuk provinsi Lampung sendiri, pada tahun 2009 kasus BTA positif sebanyak 4.943. Sedangkan pada tahun 2010, kasus BTA positif sebanyak 5.139. Dari data tersebut, diketahui kasus TB paru di Lampung dari tahun ke tahun mengalami peningkatan. Pernyataan ini didukung oleh penelitian yang dilakukan Wardani (2011) bahwa selain terjadi peningkatan kasus dari tahun ke tahun penyebaran dari kasus TB tidak merata di semua daerah. Lebih jauh lagi, berdasarkan data yang diperoleh dari laporan bidang Pengendalian Penyakit dan Penyehatan Lingkungan (P3PL) TB paru Dinas Kesehatan Provinsi Lampung, angka kejadian TB paru di Lampung Hingga akhir Desember tahun 2015, angka penemuan kasus penderita TBParusebanyak 8.492 kasus dari estimasi kasus di tahun 2015 sebanyak32.128 (target strategi nasional). Angka Keberhasilan Pengobatan di Propinsi Lampung tahun 2015 sudah mencapai target yaitu 92,6\%. Sedangakan kasus TB paru di kabupaten way kanan dengan angka cure rate (CR) di kabupaten way kanan sebanyak 92,83 (Dinas Kesehatan Provinsi Lampung, 2015).

Solusi yang tepat untuk mengatasi penyakit ini dapat dilakukan pencegahan sedini mungkin. Pengetahuan sebagian masyarakat mengenai tanda-tanda penyakit TBC relatif cukup baik, sikap masyarakat masih kurang peduli terhadap akibat yang dapat ditimbulkan oleh penyakit TBC, perilaku dan kesadaran sebagian masyarakat untuk

Wahid Tri Wahyudi' Program Studi llmu Keperawatan Universitas Malahayati Bandar Lampung.

Email : wahid@malahayati.ac.id

Suprihatin ${ }^{2}$ Puskesmas Negeri Agung Kabupaten Way Kanan. Email : supri_wk@yahoo.com 
memeriksakan dahak dan menggunakan fasilitas pelayanan kesehatan masih kurang, karena mereka malu dan takut divonis menderita TBC (Media, 2010).

Terdapat hubungan yang bermakna antara sikap pencegahan dan pencarian pengobatan serta tingkat pendidikan masyarakat terhadap penyakit TBC di kota Surakarta. Dan tidak ada hubungan yang bermakna antara tingkat penghasilan, pengetahuan dan praktek pencarian pengobatan terhadap penyakit TBC di kota Surakarta (Handoko, 2010).

Terdapat hubungan yang bermakna antara pengetahuan, sikap, tingkat pendidikan, kepadatan hunian rumah dan luas ventilasi rumah dengan pencegahan penularan penyakit tuberkulosis. Serta deter minan yang paling besar pengaruhnya adalah tingkat pendidikan, kepadatan hunian dan pengetahuan (Wahyuni, 2008). .

Pencegahan penyakit merupakan komponen penting dalam pelayanan kesehatan. Perawatan pencegahan melibatkan aktivitas peningkatan kesehatan termasuk program pendidikan kesehatan khusus, yang dibuat untuk membantu klien menurunkan risiko sakit, mempertahankan fungsi yang maksimal, dan meningkatkan kebiasaan yang berhubungan dengan kesehatan yang baik (Potter, \& Perry, 2010). Upaya pencegahan penyakit tuberkulosis dilakukan untuk menurunkan angka kematian yang disebabkan oleh penyakit tuberkulosis.

Pengetahuan atau kognitif merupakan domain yang sangat penting dalam membentuk tindakan seseorang (overt behavior). Pengetahuan yang baik apabila tidak ditunjang dengan sikap yang positif yang diperlihatkan akan mempengaruhi seseorang untuk berperilaku (Benyamin Bloom, 2003; Notoatmodjo, 2010). yang menyatakan bahwa domain dari perilaku adalah pengetahuan, sikap dan tindakan (Notoadmodjo, 2010).

Sikap dan praktek yang tidak didasari oleh pengetahuan yang adekuat tidak akan bertahan lama pada kehidupan seseorang, sedangkan pengetahuan yang adekuat jika tidak diimbangi oleh sikap dan praktek yang ber kesinambungan tidak akan mempunyai makna yang berarti bagi kehidupan. Maka dari itu pengetahuan dan sikap merupakan penunjang dalam melakukan perilaku sehat salah satunya upaya pencegahan penyakit tuberkulosis.

Kasus penyakit tuberkulosis di wilayah Kerja Puskesmas Negeri Agung Kabupaten Way Kanan cukup tinggi. Data kasus penyakit tuberkulosis yang tercatat di Puskesmas Negeri Agung Kabupaten Way Kanan menunjukkan tahun 2014 perkiraan suspek : 536 , perkiraan BTA (+) : 54 dan ditemukan Jumlah suspek tercapai : 145 dan Jumlah BTA (+) : 14. tahun 2015 Target suspek: 560 Orang, Target BTA (+) : 56 Orang dan ditemukan Jumlah suspek: 101 dan Jumlah BTA (+) : 16. Tahun 2016 Target suspek : 560 dan Target BTA (+) : 56 ditemukan Jumlah suspek : 200 Jumlah BTA (+) : 23. Dari data monev 3 tahun terakhir di Kecamatan Negeri Agung masih cukup tinggi meskipun nilai suspect dan BTA $(+)$ menurun namun angka kasus Tuberculosis masih cukup tinggi (Dinas Kesehatan Way Kanan, 2016)

\section{METODE PENELITIAN}

Penelitian ini adalah penelitian kuantitatif yaitu penelitian yang di dasarkan pada data kuantitatif dimana data kuantitatif adalah data yang berbentuk angka atau bilangan dengan pendekatan katan Cross sectional. Penelitian ini dilaksanakan Di Wilayah Kerja Puskesmas Negeri Agung Kabupaten Way Kanan pada bulan Juni 2017.

Populasi dalam penelitian ini adalah semua warga suspect Di Wilayah Kerja Puskesmas Negeri Agung Kabupaten Way Kanan yang berobat ke puskesmas pada tahun 2016 sebanyak 200 jiwa. Dengan teknik sampling random sampling sampel yang digunakan sebanyak 133 sampel

Wahid Tri Wahyudi' Program Studi llmu Keperawatan Universitas Malahayati Bandar Lampung. Email : wahid@malahayati.ac.id

Suprihatin² Puskesmas Negeri Agung Kabupaten Way Kanan. Email : supri_wk@yahoo.com 
HASIL

Tabel 1. Tentang Karakteristik Responden Berdasarkan Usia N=133

\begin{tabular}{ccc}
\hline Usia (tahun) & Jumlah $(\mathbf{n})$ & Persentase $(\%)$ \\
\hline $17-25$ & 0 & 0 \\
$26-35$ & 56 & 42,1 \\
$36-45$ & 72 & 54,1 \\
$46-50$ & 5 & 3,8 \\
Total & 133 & 100 \\
\hline
\end{tabular}

Sumber : Data Penelitian (2017)

Berdasarkan tabel 1. tentang Karakteristik Responden Berdasarkan Usia menunjukkan data bahwa responden paling banyak berusia antara $36-45$ tahun yang berjumlah $72(54,1 \%)$ responden.

Tabel 2. Tentang Karakteristik Responden Berdasarkan Jenis Kelamin N=133

\begin{tabular}{lcc}
\hline Jenis Kelamin & Jumlah $(\mathbf{n})$ & Persentase $(\%)$ \\
\hline Laki-laki & 78 & 58,6 \\
Perempuan & 55 & 41,4 \\
Total & 133 & 100 \\
\hline
\end{tabular}

Sumber : Data Penelitian (2017)

Berdasarkan tabel 2. tentang Karakteristik Responden Berdasarkan Jenis Kelamin menunjukkan data bahwa responden sebagian besar adalah laki-laki yang berjumlah 78 (58,6\%) responden.

Tabel 3. Tentang Karakteristik Responden Berdasarkan Pendidikan N=133

\begin{tabular}{|c|c|c|}
\hline Pendidikan & Jumlah (n) & Persentase (\%) \\
\hline Tidak Sekolah & 13 & 9,8 \\
\hline SD & 94 & 70,7 \\
\hline SMP & 23 & 17,3 \\
\hline SMA & 3 & 2,3 \\
\hline Total & 133 & 100 \\
\hline
\end{tabular}

Sumber : Data Penelitian (2017)

Berdasarkan tabel 3. tentang Karakteristik Responden Berdasarkan Pendidikan, menunjukkan data bahwa responden sebagian besar responden berpendidikan SD dengan jumlah $94(70,7 \%)$ responden dan selebihnya SMP berjumlah $23(17,3 \%)$ responden, SMA berjumlah $3(2,3 \%)$ responden dan tidak sekolah berjumlah $13(9,8 \%)$ responden.

Wahid Tri Wahyudi' Program Studi llmu Keperawatan Universitas Malahayati Bandar Lampung. Email : wahid@malahayati.ac.id

Suprihatin² Puskesmas Negeri Agung Kabupaten Way Kanan. Email : supri_wk@yahoo.com 
Tabel 4. Tentang Karakteristik Responden Berdasarkan Pekerjaan N=133

\begin{tabular}{lcc}
\hline Pekerjaan & Jumlah $(\mathbf{n})$ & Persentase $(\%)$ \\
\hline Petani & 37 & 27,8 \\
Buruh & 84 & 63,2 \\
Wiraswasta & 12 & 9 \\
Total & 133 & 100 \\
\hline
\end{tabular}

Sumber : Data Penelitian (2017)

Berdasarkan tabel 4. tentang Karakteristik Responden Berdasarkan Pekerjaanmenunjukkan data bahwa responden sebagian besar responden bekerja sebagai Buruh dengan jumlah $84(63,2 \%)$ responden, selebihnya Wiraswasta berjumlah $12(9 \%)$ responden, dan petani berjumlah $37(27,8 \%)$ responden.

Tabel 5. Tentang Karakteristik Responden Berdasarkan Status Penghasilan $\mathrm{N}=133$

\begin{tabular}{lcc}
\hline Penghasilan & Jumlah $(\mathbf{n})$ & Persentase $(\%)$ \\
\hline$<$ Rp. 1.000 .000 & 87 & 65,4 \\
$\geq$ Rp. 1.000 .000 & 46 & 34,6 \\
Total & 133 & 100 \\
\hline
\end{tabular}

Sumber : Data Penelitian (2017)

Berdasarkan tabel 5. tentang Karakteristik Responden Berdasarkan Status Penghasilan menunjukkan data bahwa responden yang berpenghasilan < Rp. 1.000 .000 yakni berjumlah $87(65,4 \%)$ responden.

Tabel 6. Tentang Distribusi Frekuensi Pengetahuan Responden N=133

\begin{tabular}{lcc}
\hline Pengetahuan & Jumlah $(\mathbf{n})$ & Persentase $(\%)$ \\
\hline Kurang Baik & 84 & 63,2 \\
Baik & 49 & 36,8 \\
Total & 133 & 100 \\
\hline
\end{tabular}

Sumber : Data Penelitian (2017)

Berdasarkan tabel 6. tentang distribusi frekuensi pengetahuan menunjukkan responden yang memiliki tingkat pengetahuan kurang baik sebanyak $84(63,2 \%)$, sedangkan responden yang memiliki tingkat pengetahuan baik sebanyak 49 (36,8\%) responden, hal ini menunjukkan bahwa jumlah memiliki tingkat pengetahuan kurang baik lebih besar dibandingkan dengan responden yang memiliki tingkat pengetahuan baik.

Wahid Tri Wahyudi' Program Studi llmu Keperawatan Universitas Malahayati Bandar Lampung. Email : wahid@malahayati.ac.id

Suprihatin² Puskesmas Negeri Agung Kabupaten Way Kanan. Email : supri_wk@yahoo.com 
Tabel 7. Tentang Distribusi Frekuensi Upaya Deteksi Dini $\mathrm{N}=133$

\begin{tabular}{lcc}
\hline $\begin{array}{l}\text { Upaya deteksi } \\
\text { dini }\end{array}$ & Jumlah $(\mathbf{n})$ & $\begin{array}{c}\text { Persentase } \\
(\%)\end{array}$ \\
\hline Tidak & 111 & 83,5 \\
Melakukan & & \\
Melakukan & 22 & 16,5 \\
Total & 133 & 100 \\
\hline
\end{tabular}

Sumber : Data penelitian (2017)

Berdasarkan tabel 7. tentang distribusi frekuensi Upaya deteksi dini menunjukkan responden yang tidak melakukan deteksi dini sebanyak $111(83,5 \%)$, responden yang melakukan deteksi dini sebanyak $22(16,5 \%)$, hal ini menunjukkan bahwa jumlah responden yang tidak melakukan deteksi dini lebih banyak dilakukan dari pada responden yang melakukan deteksi dini.

Tabel 8. Hubungan Upaya Deteksi Dini dan Pengetahuan Responden N=133

\begin{tabular}{ccccccccc}
\hline & \multicolumn{3}{c}{ Upaya deteksi dini } & & \multirow{2}{*}{ Total } & \multirow{2}{*}{ p-value } & \multirow{2}{*}{ Odd Rasio } \\
\cline { 2 - 7 } Pengetahuan & \multicolumn{2}{c}{ Tidak melakukan } & \multicolumn{2}{c}{ Melakukan } & & & \\
\cline { 2 - 7 } & $\mathbf{n}$ & $\%$ & $\mathbf{n}$ & $\%$ & $\mathbf{N}$ & $\%$ & & \\
\hline Kurang Baik & 75 & 89,3 & 9 & 10,7 & 84 & 100 & \multirow{2}{*}{0,033} & 3,009 \\
Baik & 36 & 73,5 & 13 & 26,5 & 49 & 100 & & \\
Total & $\mathbf{1 1 1}$ & $\mathbf{8 3 , 5}$ & $\mathbf{2 2}$ & $\mathbf{1 6 , 5}$ & $\mathbf{1 3 3}$ & $\mathbf{1 0 0}$ & & \\
\hline
\end{tabular}

Sumber : Data penelitian (2017)

Berdasarkan tabel 8. di atas dapat diketahui bahwa dari 133 responden dengan kategori responden yang memiliki tingkat pengetahuan kurang baik dan tidak melakukan upaya deteksi dini sebanyak 75 (89,3\%) responden, dan responden yang memiliki tingkat pengetahuan baik dan yang melakukan upaya deteksi dini sebesar $13(26,5 \%)$ responden. Berdasarkan hasil analisi dalam tabel 4.8 menunjukkan bahwa $p$ value $=0,033(<0,05)$; hal ini berarti menunjukkan adanya hubungan antara pengetahuan dengan upaya deteksi dini penyakit tuberkulosis paru. Nilai odd ratio pada penelitian ini sebesar 3,009; dengan nilai confidence interval 95\% dimana batas lower 2.481 dan batas upper 36.378; yang artinya responden yang memiliki tingkat pengetahuan tidak baik memiliki kecenderungan untuk tidak melakukan upaya deteksi dini 3 kali lebih besar dibandingkan dengan responden yang memiliki tingkat pengetahuan baik.

\section{PEMBAHASAN}

\section{Domain Pengetahuan}

Berdasarkan tabel tentang distribusi frekuensi pengetahuan menunjukkan bahwa jumlah yang memiliki tingkat pengetahuan kurang baik lebih besar dibandingkan memiliki tingkat pengetahuan baik yakni sebesar $63,2 \%$. Pengetahuan merupakan hasil dari tahu, dan ini terjadi setelah orang melakukan pengindraan suatu kejadian tertentu.
Pengindraan terjadi melalui pancaindra manusia, yakni indra penglihatan, pendengaran,penciuman, rasa, dan raba. Sebagian besar pengetahuan manusia diperoleh melalui mata dan telinga (Notoatmodjo, 2010).

Pengetahuan merupakan domain yang sangat penting dalam terbentuknya suatu tindakan. Dengan demikian terbentuknya perilaku terhadap seseorang karena adanya pengetahuan yang ada pada dirinya terbentuknya suatu perilaku baru, terutama yang

Wahid Tri Wahyudi Program Studi llmu Keperawatan Universitas Malahayati Bandar Lampung. 
ada pada orang dewasa dimulai pada domain kognitif. Dalam arti seseorang terlebih dahulu diberi stimulus yang berupa informasi tentang upaya pencegahan penyakit TBC sehingga menimbulkan pengetahuan yang baru, dan selanjutnya menimbulkan respon batin dalam bentuk sikap pada orang tersebut terhadap informasi upaya pencegahan penyakit TBC yang diketahuinya. Akhirnya rangsangan yakni informasi upaya pencegahan penyakit TBC yang telah diketahuinya dan disadari sepenuhnya tersebut akan menimbulkan respon lebih jauh lagi yaitu berupa tindakan atau sehubungan dengan stimulus atau informasi upaya pencegahan penyakit TBC (Notoatmodjo, 2010).

Penelitian yang dilakukan Bagas Wirasti Tahun 2010 dengan judul Hubungan Antara Karakteristik dan Pengetahuan Tentang Tuberkulosis Paru Dengan Perilaku Penularan Tuberkulosis Paru Di Puskesmas Sawangan Kota Depok Tahun 2010 disimpulkan bahwa terdapat hubungan yang bermakna antara pengetahuan masyarakat dengan upaya pencegahan tuberkulosis di RW 04 kelurahan lagoa dengan nilai $P$ sebesar 0,000 serta memiliki hubungan positif yang sedang dengan nilai $r$ sebesar 0,541 artinya semakin baik tingkat pengetahuan maka semakin baik upaya pencegahan penyakit tuberkulosis pada masyarakat RW 04 kelurahan lagoa.

Sedangkan dari peneliti menyimpulkan dari penelitian diatas bahwa faktor yang mempengaruhi terbentuknya pengetahun adalah : Pendidikan, Sosial, budaya, dan ekonomi, Usia.

\section{Domain Upaya Deteksi Dini}

Berdasarkan tabel tentang distribusi frekuensi Upaya deteksi dini menunjukkan bahwa jumlah responden yang tidak melakukan upaya deteksi dini lebih banyak dilakukan dari pada responden yang melakukan deteksi dini yakni sebesar 83,5\%. Upaya penanggulangan penyakit TB sudah dilakukan melalui berbagai program kesehatan di tingkat Puskesmas, berupa pengembangan strategi penanggulangan TB yang dikenal sebagai strategi DOTS (directly observed treatment, Short course = pengawasan langsung menelan obat jangka pendek), yang telah terbukti dapat menekan penularan, juga mencegah perkembangannya MDR (multi drugs resistance = kekebalan ganda terhadap obat )-TB, tetapi hasilnya masih dirasakan belum sesuai dengan yang diharapkan (Manalu, 2010).

Penelitian yang dilakukan Bagas Wirasti Tahun 2010 dengan judul Hubungan Antara Karakteristik dan Pengetahuan Tentang Tuberkulosis Paru Dengan Perilaku Penularan Tuberkulosis Paru Di Puskesmas Sawangan Kota Depok Tahun 2010 di didapatkan hasil bahwa pengetahuan masyarakat sebagaian besar memiliki pengetahuan yang baik tentang penyakit tuberkulosis sebesar $71.7 \%$, dan disimpulkan bahwa terdapat hubungan yang bermakna antara sikap masyarakat dengan upaya pencegahan penyakit tuberkulosis di RW 04 kelurahan lagoa dengan nilai $(p=0,001)$ dan pengetahuan $(p=0,031)$.

Hasil penelitian didapatkan data bahwa seseorang yang melakukan upaya detesi dini lebih awal mampu meminimalkan terjadinya komplikasi dari penyakit TB paru. Dan setelah dilakukan wawancara mendalam dengan responden TB paru didapatkan pernyataan bahwa seseorang yang tidak melakukan deteksi dini TB paru akan terjadi penyakit Tb paru lebih cepat dibandingkan dengan yang melakukan upaya deteksi dini TB paru.

Berdasarkan hasil statistik diatas menunjukkan terdapat hubungan antara pengetahuan dengan upaya deteksi dini penyakit tuberkulosis paru ( $p$ value ; 0,033). Pengetahuan merupakan hasil dari tahu, dan ini terjadi setelah orang melakukan pengindraan suatu kejadian tertentu. Pengindraan terjadi melalui pancaindra manusia, yakni indra penglihatan, pendengaran,penciuman, rasa, dan raba. Sebagian besar pengetahuan manusia diperoleh melalui mata dan telinga (Notoatmodjo, 2010).

Pengetahuan merupakan domain yang sangat penting dalam terbentuknya suatu tindakan. Dengan demikian terbentuknya perilaku terhadap seseorang karena adanya pengetahuan yang ada pada dirinya terbentuknya suatu perilaku baru, terutama yang ada pada orang dewasa dimulai pada domain kognitif. Dalam arti seseorang terlebih dahulu diberi stimulus yang berupa informasi tentang upaya pencegahan penyakit TBC sehingga menimbulkan pengetahuan yang baru, dan selanjutnya menimbulkan respon batin dalam bentuk sikap pada orang tersebut terhadap informasi upaya

Wahid Tri Wahyudi' Program Studi llmu Keperawatan Universitas Malahayati Bandar Lampung.

Email : wahid@malahayati.ac.id

Suprihatin ${ }^{2}$ Puskesmas Negeri Agung Kabupaten Way Kanan. Email : supri_wk@yahoo.com 
pencegahan penyakit TBC yang diketahuinya. Akhirnya rangsangan yakni informasi upaya pencegahan penyakit TBC yang telah diketahuinya dan disadari sepenuhnya tersebut akan menimbulkan respon lebih jauh lagi yaitu berupa tindakan atau sehubungan dengan stimulus atau informasi upaya pencegahan penyakit TBC (Notoatmodjo, 2010).

Faktor risiko yang menyebabkan penyakit TBC (uapaya deteksi dini) adalah: faktor umur, faktor jenis kelamin,tingkat pendidikan, pekerjaan, dan Penghasilan (Widoyono,2011). Dari pembahasan hasil dan teori diatas diperoleh kesimpulan bahwa terdapat hubungan antara umur (rata-rata 36 tahun), jenis kelamin (penderita TBC lebih banyak laki-laki dibandingkan dengan perempuan), pendidikan (semakin rendah tingkat pendidikan mempengaruhi tingkat pengetahuan responden terkait upaya deteksi dini peyakit TBC), pekerjaan, penghasilan (status ekonomi), dan pengetahuan (upaya deteksi dini / pencegahan) terhadap penyakit tuberkulosis.

Berdasarkan penelitian terkait yang dilakukan oleh Wirasti Tahun 2010 dengan judul Hubungan Antara Karakteristik dan Pengetahuan Tentang Tuberkulosis Paru Dengan Perilaku Penularan Tuberkulosis Paru Di Puskesmas Sawangan Kota Depok Tahun 2010. Jenis penelitian ini adalah deskriptif analitik dengan pendekatan cross sectional. Sampel adalah penderita TBC yang tercatat di Puskesmas Sawangan Depok yang berjumlah 33 orang, di ambil menggunakan metode sampling jenuh. Hasil yang didapatkan dari penelitian tersebut menunjukkan variabel yang mempunyai hubungan signifikan terhadap perilaku pencegahan penularan TB adalah pendidikan $(p=$ $0,001)$, pekerjaan $(p=0,046)$ dan pengetahuan $(p=$ 0,031).

Penelitian terkait diatas menunjukkan kesamaan hasil antara penelelitian yang telah dilakukan sebelumnya dengan penelitian yang telah peneliti lakukakan saat ini, yakni terdapat hubungan yang bermakna.

Menurut analisa peneliti hasil yang didapat yakni ada Hubungan Pengetahuan Dengan Upaya Deteksi Dini penyakit Tuberkulosis paru ( $p$ value= 0,033 ), terdapat hubungan antara hasil dalam penelitian ini, teori yang sudah ada, dan penelitian terkait yang sudah pernah dilakukan sebeunmnya.
Dan menurut peneliti tingkat kecemasan masyarakat berbeda-beda dalam penanganan masalah yang dialami oleh masyarakat tersebut, seperti halnya dalam masalah pemberian pengetahuan dalam penyuluhan Tb Paru. Dan juga menurut peneliti faktor yang mempengaruhi tingkat pengetahuan itu salah satunya adalah tingkat pendidikan, yang mana semakin seseorang itu tinggi pendidikan yang diperoleh maka otomatis seseorang itu akan mendapatkan informasi yang lebih dibandingkan dengan tingkat pendidikan yang rendah.

\section{SIMPULAN}

Berdasarkan hasil penelitian dan pembahasan tentang hubungan pengetahuan dengan upaya deteksi dini penyakit Tb Paru Di Wilayah Kerja Puskesmas Negeri Agung Kabupaten Way Kanan Tahun 2017, dapat disimpulkan sebagai berikut:

Didapatkan hasil bahwa pengetahuan kurang baik masyarakat tentang TB paru sebesar $63,2 \%$, responden yang tidak melakukan upaya deteksi dini penyakit Tb Paru sebesar 83,5\%. Didapatkan hasil bahwa $p$ value $<0,05$ yaitu bahwa $\mathrm{H}_{0}$ ditolak yang artinya ada hubungan yang bermakna (signifikan) antara pengetahuan dengan upaya deteksi dini penyakit tuberkulosis paru ( $p$ value; 0,033 ).

\section{SARAN}

Berdasarkan kesimpulan dari hasil penelitian hubungan pengetahuan dengan upaya deteksi dini penyakit Tb Paru, maka penulis memberikan saran yang dapat mungkin digunakan sebagai bahan pertimbangan yaitu: Puskesmas harus melakukan pencegahan deteksi dini melalui pemeriksaanpemeriksaan sesuai kebijakan yang telah ditetapkan puskesmas. Masyarakat perlu diberikan motivasi supaya aktif berpartisipasi dalam program pemeriksaan tuberkulosis paru dengan menambah pemahaman masyarakat akan pentingnya melakukan deteksi dini.

\section{DAFTAR PUSTAKA}

Astuti, S. (2013). Hubungan tingkat pengetahuan dan sikap masyarakat terhadap upaya pencegahan penyakit Tuberkulosis di rw 04 Kelurahan Lagoa Jakarta Utara Tahun 2013.

Wahid Tri Wahyudi Program Studi llmu Keperawatan Universitas Malahayati Bandar Lampung.

Email : wahid@malahayati.ac.id

Suprihatin ${ }^{2}$ Puskesmas Negeri Agung Kabupaten Way Kanan. Email : supri_wk@yahoo.com 
Becker, G. S., \& Tomes, N. (1979). An equilibrium theory of the distribution of income and intergenerational mobility. Journal of political Economy, 87(6), 1153-1189.

Bloom, B. S. (2003). Taxonomy of Educational Objective: Handbook 7. New York: Cognative Domain.

Denila, D., \& Samingan, S. (2017). Hubungan tingkat pengetahuan dan sikap masyarakat terhadap upaya pencegahan penyakit Tuberkulosis di Kelurahan Pulogadung Jakarta Timur Tahun 2016. Jurnal Bidang IImu Kesehatan, 10(2).

Departemen Kesehatan Republik Indonesia. (2011). TBC masalah kesehatan dunia.

Departemen Kesehatan Republik Indonesia.(2013). Riset. Kesehatan dasar. 2007. Diunduh tanggal, 21.

Dinas Kesehatan Way Kanan. (2016). Data laporan Tuberkulosis Paru. Puskesmas Negeri Agung. Way Kanan. Provinsi Lampung

Djannah, S. N., Suryani, D., \& Purwati, D. A. (2009). Hubungan tingkat pengetahuan dan sikap dengan perilaku pencegahan penularan TBC pada mahasiswa di asrama manokwari Sleman Yogyakarta. Universitas Ahmad Dahlan.

Djojodibroto, R. D., Pratibha, G., Kamaluddin, B., Manjit, S. S., Sumitabha, G., Deva Kumar, A., \& Hashami, B. (2009). Predicted equations for ventilatory function among kuching (Sarawak, Malaysia) population. Medical Journal of Malaysia, 64(4), 275-279.

Handoko, N.(2010). Hubungan Tingkat Penghasilan, Pendidikan, Pengetahuan, Sikap Pencegahan dan Pencarian Pengobatan, Praktek Pencegahan dan Pencarian Pengobatan dengan Penyakit TBC di BBKPM Surakarta. Jurnal Keperawatan, 1(1), 1-7.

Hidayat, A. (2007). Metode Penelitian Keperawatan dan Teknik Penulisan IImiah.
Kementrian Kesehatan Republik Indonesia. (2012). Profil data kesehatan Indonesia tahun 2011. Jakarta: Kementerian Kesehatan Republik Indonesia.

Manalu, H. S. P. (2010). Faktor-faktor yang mempengaruhi kejadian TB paru dan upaya penanggulangannya. Indonesian Journal of Health Ecology, 9(4).

Media. (2010). Pengetahuan, Sikap Dan Perilaku Masyarakat Tentang Penyakit Tuberkulosis (Tb) Paru Di Kecamatan Sungai Tarab, Kabupaten Tanah Datar. Media Penelitian dan Pengembangan Kesehatan

Muttaqin, A. (2008). Askep Klien dengan Gangguan Sistem Pernapasan.

Notoatmodjo, S. (2010). Domain perilaku. Promosi kesehatan dan ilmu perilaku. Jakarta: Rineka Cipta.

Notoatmodjo, S. (2010). IImu perilaku kesehatan. Jakarta: Rineka Cipta, 200, 26-35.

Notoatmodjo, S. (2010). Metodologi penelitian kesehatan.

Notoatmodjo, S. (2010). Promosi kesehatan dan ilmu perilaku. Jakarta: Rineka Cipta, 20.

Potter, P. A., \& Perry, A. G. (2004). Fundamentals of nursing.

Robert, C., Thomas, L., Bondarenko, I., O'Day, S., Weber, J., Garbe, C., ... \& Davidson, N. (2011). Ipilimumab plus dacarbazine for previously untreated metastatic melanoma. New England Journal of Medicine, 364(26), 2517-2526.

Siswanto, S., Susila, D., \& Suyanto, D. (2013). Metodologi Penelitian Kesehatan dan Kedokteran. Yogyakarta: Bursa IImu.

Sugiyono. (2010). Metode penelitian pendidikan:(pendekatan kuantitatif, kualitatif dan $R \& D)$. Alfabeta.

Wahid Tri Wahyudi' Program Studi llmu Keperawatan Universitas Malahayati Bandar Lampung.

Email : wahid@malahayati.ac.id

Suprihatin² Puskesmas Negeri Agung Kabupaten Way Kanan. Email : supri_wk@yahoo.com 
Swarjana, I. K., (2015). Metodologi Penelitian Kesehatan [Edisi Revisi]: Tuntunan Praktis Pembuatan Proposal Penelitian untuk Mahasiswa Keparawatan, Kebidanan, dan Profesi Bidang Kesehatan Lainnya. Penerbit Andi.

Syarah, M. M., \& Rahmawati, M. (2017). Komunikasi Partisipatori Pada Program Pemberdayaan Masyarakat Dalam Penanganan TB. CakrawalaJurnal Humaniora, 17(2), 250-257.

Wahyuni, W. (2008). Determinan perilaku masyarakat dalam pencegahan, penularan penyakit tbc di wilayah kerja puskesmas bendosari. Gaster: Jurnal Kesehatan, 4(1), 178183.
Wibowo, A. (2014). Metodologi penelitian praktis bidang kesehatan. Jakarta: Rajawali Pers, 6.

Widoyono, P. T., \& Epidemiologi, P.(2011). Pencegahan \& Pemberantasannya. Semarang: Erlangga, 112-25.

World Health Organization (Ed.). (2013). Global tuberculosis report 2013. World Health Organization.

Wahid Tri Wahyudi' Program Studi llmu Keperawatan Universitas Malahayati Bandar Lampung.

Email : wahid@malahayati.ac.id

Suprihatin² Puskesmas Negeri Agung Kabupaten Way Kanan. Email : supri_wk@yahoo.com 